\title{
Pengaruh Model Pembelajaran Consept Sentence Berbantuan Media Audio Visual Terhadap Keterampilan Menulis Bahasa Indonesia
}

\author{
Ni Wyn Serra Yuni Ari Cahyani ${ }^{1}$, Ni Nyoman Ganing ${ }^{2}$, I Ketut Adnyana Putra ${ }^{3}$ \\ 1,2,3 Jurusan Pendidikan Guru Sekolah Dasar, FIP Universitas Pendidikan Ganesha \\ Singaraja, Indonesia \\ e-mail: serrayuni@gmail.com ${ }^{1}$, nyomanganing@yahoo.co.id ${ }^{2}$, \\ ketut.adnyana.putra@undiksha.ac.id ${ }^{3}$
}

\begin{abstract}
Abstrak
Penelitian ini bertujuan untuk mengetahui pengaruh model pembelajaran consept sentence berbantuan media audio visual terhadap keterampilan menulis Bahasa Indonesia siswa kelas II SD Gugus Patimura Denpasar Selatan tahun ajaran 2017/2018. Penelitian ini merupakan penelitian eksperimen semu dengan rancangan nonequivalent control grup design. Populasi penelitian ini adalah siswa kelas II SD Gugus Patimura Denpasar Selatan yang terdiri dari 306 siswa. Sampel penelitian ini adalah sebanyak 72 orang siswa, 36 orang siswa kelas lla SD Negeri 11 Sesetan sebagai kelompok eksperimen dan sebanyak 36 orang siswa kelas II SD Negeri 18 Sesetan sebagai kelompok kontrol. Pengumpulan data keterampilan menulis permulaan dilakukan dengan metode tes uraian. Data yang diperoleh dianalisis dengan analisis uji-t. Berdasarkan hasil analisis diperoleh $t_{\text {hitung }}=3,659>t_{\text {tabel }}=2,000$, sehingga Ho ditolak dan Ha diterima yang berarti terdapat perbedaan yang signifikan keterampilan menulis Bahasa Indonesia antara kelompok siswa yang dibelajarkan melalui model pembelajaran consept sentence berbantuan media audio visual dengan kelompok siswa yang dibelajarkan melalui pembelajaran konvensional. Nilai rata-rata keterampilan menulis permulaan pada kelompok eksperimen yaitu $\bar{X}=84,183$ dan rata-rata keterampilan menulis permulaan kelompok kontrol yaitu $\bar{X}=75,208$. Dengan demikian, dapat disimpulkan bahwa terdapat pengaruh model pembelajaran consept sentence berbantuan media audio visual terhadap keterampilan menulis Bahasa Indonesia siswa kelas II SD Gugus Patimura Denpasar Selatan tahun ajaran 2017/2018. Berdasarkan hasil penelitian disarankan agar penelitian ini dapat dijadikan hasil kajian yang lebih luas dan memperdalam teori mengenai model pembelajaran consept sentence berbantuan media audio visual.
\end{abstract}

Kata Kunci: consept sentence, audio visual, keterampilan menulis.

\begin{abstract}
This study aims to determine the impact of concept sentence learning model assisted audiovisual media on the skill of writing Indonesian subject of students class II SD Gugus Patimura Denpasar Selatan academic year 2017/2018. This research is a quasi-experimental research with non-equivalent control group design. The population of this research is the second-grade students of SD Gugus Patimura Denpasar Selatan which consists of 306 students. The sample of the research is 72 students, 36 students of class Ila SD Negeri 11 Sesetan as an experimental group and 36 students of class II Sd Negeri 18 Sesetan as a control group. The data of the early writing was done by the essay test method. The data gained by t-test analysis. Based on the result of the data analysis $t_{\text {hitung }}=3,659>t_{\text {tabel }}=2,000$, Ho was declined and $\mathrm{Ha}$ was accepted which there were significant differences in the skill of writing Indonesian subjects among groups of students learned through sentence learning model assisted audiovisual media with the group who learned through conventional learning. The average of the early writing skill in the experimental group was $\bar{X}=84,183$ and the average of the control group was $\bar{X}=75,208$. Thus, it can be concluded that there was an impact of concept sentence learning model assisted audiovisual media on the writing skill of Indonesian subject of students second grade SD Gugus Patimura Denpasar Selatan academic year 2017/2018. Based on the results of the study suggested this study can be used as a result of a wider assessment and deepen the theory of learning concept sentence model audiovisual media
\end{abstract}

Keywords: concept sentence, audiovisual, writing skill. 


\section{Pendahuluan}

Pasal 1 UU SISDIKNAS no. 20 tahun 2003 disebutkan bahwa Sistem Pendidikan Nasional adalah keseluruhan komponen pendidikan yang saling terkait secara terpadu untuk mencapai tujuan pendidikan nasional. Berangkat dari bunyi pasal ini dapat diketahui bahwa pendidikan adalah sistem yang merupakan suatu totalitas struktur yang terdiri dari komponen yang saling terkait dan secara bersama menuju kepada tercapainya tujuan (Soetarno, 2003: 2). Adapun komponen-komponen dalam pendidikan nasional antara lain adalah lingkungan, sarana-prasarana, sumberdaya, dan masyarakat. Komponen-komponen tersebut bekerja secara bersama-sama, saling terkait dan mendukung dalam mencapai tujuan pendidikan (Munirah ,2015).

Bahasa Indonesia merupakan suatu mata pelajaran yang sangat strategis, yakni sebagai Bahasa pengantar pendidikan dan Bahasa Nasional. Pembelajaran Bahasa Indonesia diarahkan untuk meningkatkan kemampuan siswa dalam berkomunikasi baik dengan lisan maupun tulisan. Keterampilan berbahasa mempunyai empat komponen, yaitu "1) keterampilan menyimak (listening skills), 2) keterampilan berbicara (speaking skills), 3) keterampilan membaca (reading skills), dan 4) keterampilan menulis (writing skills)" (Tarigan, 2013: 1).

Bahasa Indonesia memiliki kedudukan sangat penting, yaitu sebagai bahasanasional dan bahasa negara. Chaer (2003: 33) mengemukakan bahwa bahasa sebagi lambang bunyi yang arbitrer atau manasuka memiliki fungsi yaitu: (1) fungsi informasi adalah fungsi untuk menyampaikan pesan atau amanat kepada orang lain, (2) fungsi eksplorasi adalah penggunaan penggunaan bahasa untuk menjelaskan suatu hal, perkara, dan keadaan, (3) fungsi persuasi adalah penggunaan bahasa yang bersifat mempengaruhi atau mengajak orang lain untuk melakukan atau tidak melakukan sesuatu secara baik-baik dan (4) fungsi entertainment adalah penggunaan bahasa dengan maksud menghibur, menyenangkan, atau memuaskan perasaan batin (Nurlaila, 2016).

Empat keterampilan ini saling berhubungan satu dengan yang lainnya, seperti di dalam proses pembelajaran sebelum membelajarkan keterampilan menulis, siswa diminta untuk menyimak materi yang diberikan oleh guru, kemudian siswa diajak mengomunikasikan materi yang telah disimak atau diberi motivasi untuk bertanya tentang materi yang belum dipahami kemudian siswa diajak untuk membaca materi tersebut pada buku yang telah tersedia guna untuk mengarahkan siswa belajar mandiri, menemukan sendiri dan memecahkan masalah yang didapatnya, setelah itu barulah siswa menulis kesimpulan dari materi yang telah dipelajari dengan bahasa tulisan meraka sendiri agar mudah untuk dipahaminya.

Dari empat keterampilan dasar dalam Bahasa Indonesia, pada penelitian ini akan dibahas tentang keterampilan menulis. Seperti yang diungkapkan oleh Tarigan (2013:3) "menulis merupakan suatu keterampilan berbahasa yang dipergunakan untuk berkomunikasi secara tidak langsung, tidak secara tatap muka dengan orang lain".

Berdasarkan hasil wawancara dengan Guru kelas II SD Gugus Patimura Denpasar Selatan diperoleh informasi bahwa keterampilan menulis siswa belum optimal sehingga tulisan yang dibuat oleh siswa sulit dipahami dan pesan yang ingin disampaikan terkadang susah untuk dimengerti. Hal ini disebabkan oleh beberapa faktor antara lain : (1) kurangnya motivasi dalam menulis, (2) siswa masih kesulitan dalam menuangkan ide/gagasan dalam bentuk tulisan, (3) perbendaharaan kata yang dimiliki siswa masih kurang memadai, dan (4) penggunaan ejaan, tanda baca, serta penggunaan huruf kapital juga kurang tepat.

Selain faktor dari siswa, terdapat beberapa faktor dari proses pembelajaran diantaranya yaitu : (1) proses pembelajaran siswa cenderung berpusat pada guru, (2) sumber belajar yang digunakan guru hanya memanfaatkan buku ajar saja, sehingga menimbulkan rasa bosan pada siswa, dan (3) media yang digunakan kurang bervariasi sehingga hal tersebut berdampak pada kurang optimalnya keterampilan menulis siswa. Untuk dapat membelajarkan siswa agar berpartisipasi aktif dalam proses pembelajaran serta penggunaan media kurang bervariasi, guru dituntut untuk lebih kreatif dalam mengembangkan proses pembelajaran. Dapat menerapkan model pembelajaran yang inovatif, media dan sumber belajar yang beragam guna menumbuhkan motivasi siswa dalam belajar, khususnya menulis.

Model pembelajaran Tipe concept sentence merupakan salah satu tipe model pembelajaran yang dikembangkan dari cooperative learning yang bentuk pelaksanaan pembelajarannya berupa konsep dengan menggunakan kata kunci. Sejalan dengan hal tersebut, Suprijono (2014:9) berpendapat bahwa konsep merupakan kata kunci. Tetapi tidak semua kata bisa disebut kata kunci jika kata itu tidak bersifat umum dan abstrak (Awing ,2017). 
Model complete sentence merupakan rangkaian proses pembelajaran yang diawali dengan menyampaikan materi ajar oleh guru, atau dengan penganalisaan terhadap modul yang telah dipersiapkan, pembagian kelompok yang tidak lebih dari tiga orang dengan kemampuan yang heterogen, pemberian lembar kerja yang berisi paragraf yang belum lengkap, lalu diberikan kesempatan kepada siswa untuk berdiskusi dan diakhiri dengan pengambilan kesimpulan (Wartini, 2017).

Sebagai salah satu keterampilan dasar berbahasa yang berperan penting dalam proses pembelajaran, guru sangat perlu membuat siswa lebih bersemangat dalam menulis. salah satu inovasi model pembelajaran yang dapat diterapkan disekolah dasar untuk menunjang keterampilan menulis siswa yaitu menggunakan model pembelajaran Consept Sentence.

"Model pembelajaran Consept Sentence adalah model pembelajaran yang dilakukan dengan memberikan kartu - kartu yang berisi beberapa kata kunci kepada siswa. Kemudian, kata kunci tersebut disusun menjadi beberapa kalimat dan dikembangkan menjadi paragraf paragraf" (Shoimin, $2014: 37$ ).

Kebaikan model consept sentence adalah guru lebih menuntut siswa untuk berfikir kreatif. Dalam pembelajaran, model ini memiliki banyak kelebihan, yaitu meningkatkan semangat belajar siswa, membantu terciptanya suasana belajar yang kondusif, memunculkan kegembiraan dalam belajar, mendorong dan mengembangkan proses berpikir kreatif, mendorong siswa untuk memandang sesuatu dalam pandangan yang berbeda, memunculkan kesadaran untuk berubah menjadi lebih baik, memperkuat kesadaran diri, lebih memahami kata kunci dari materi pokok pelajaran, dan siswa yang lebih pandai mengajari siswa yang kurang pandai (Qurrati ,2018).

Concept Sentence pada hakikatnya merupakan pengembangan bagan dari concept attainment yang dikembangkan dari pakar psikologi kognitif, Jerome Bruner 1967(dalam Huda, 2013:315).Concept diartikan sebagai konsep.Sedangkan dalam kamus besar bahasa Indonesia, konsep adalah ide atau pengertian yang diabstrakkan dari peristiwa konkret atau gambaran mental dari objek, proses, atau apapun yang ada di luar bahasa (Cahya ,2015).

Model pembelajaran Consept Sentence ini dapat digunakan dalam mata pelajaran Bahasa Indonesia khususnya untuk melatih keterampilan menulis karena model pembelajaran ini dapat mendorong dan mengembangkan proses berpikir kreatif siswa. Model pembelajaran Consept Sentence berbantuan media Audio Visual mendukung sebuah pembelajaran yang aktif dan efektif antara pendidik dengan peserta didiknya.

"Media Audio Visual merupakan media yang menampilkan unsur gambar (visual) dan suara (auditif) secara bersamaan pada saat mengomunikasikan pesan atau informasi" (Wati, 2016 :43). Maka pembelajaran seperti ini diharapkan berpengaruh pada keterampilan menulis.

Berdasarkan uraian sebelumnya, tujuan penelitian ini yaitu untuk mengetahui pengaruh model pembelajaran consept sentence berbantuan media audio visual terhadap keterampilan menulis Bahasa Indonesia siswa kelas II SD Gugus Patimura Denpasar Selatan Tahun Ajaran untuk mengoptimalkan keterampilan menulis siswa maka peneliti tertarik untuk menggunakan model pembelajaran Consept Sentence berbantuan media Audio Visual dalam proses pembelajaran dengan melaksanakan penelitian yang berjudul "Pengaruh Model Pembelajaran Consept Sentence Berbantuan Media Audio Visual Terhadap Keterampilan Menulis Bahasa Indonesia Siswa Kelas II SD Gugus Patimura Denpasar Selatan Tahun Ajaran 2017/2018".

\section{Metode}

Penelitian ini dilaksanakan di kelas II SD Gugus Patimura Denpasar Selatan Tahun Ajaran 2017/2018. Penelitian ini dilaksanakan selama 1 bulan yang dilaksanakan pada bulan April 2018. Perlakukan yang diberikan sebanyak 6 kali untuk kelas eksperimen dan 6 kali untuk kelas kontrol. Rancangan penelitian ini menggunakan eksperimen semu dengan desain penelitian menggunakan rancangan kelompok non - ekuivalen. Dalam desain ini terdapat dua kelompok penelitian, yaitu kelompok eksperimen dan kelompok kontrol.

Untuk kelompok eksperimen diberikan pembelajaran dengan menerapkan model pembelajaran Consept Sentence berbantuan media Audio Visual, sedangkan untuk kelompok kontrol pembelajaran secara konvensional. Tahapan penelitian ini terdiri dari tiga tahapan, yaitu tahap persiapan, tahap pelaksanaan, dan tahap akhir eksperimen. Populasi penelitian ini adalah seluruh siswa kelas II SD Gugus Patimura Denpasar Selatan yang terdiri dari 5 sekolah dan 8 kelas yang berjumlah 306 orang siswa. Dalam penelitian ini teknik yang digunakan untuk mengambil sampel adalah teknik random sampling yaitu pengambilan sampel secara acak yang dilakukan dengan cara undian. Setelah mengundi semua kelas dalam populasi untuk 
mendapatkan dua kelas sebagai sampel kemudian dua kelas tersebut akan diberikan pretest kemudian hasil pretest akan diuji kesetaraannya menggunakan uji-t. Setelah itu diundi kembali dua nama kelas tersebut untuk dijadikan kelas eksperimen dan kelas kontrol. Kedua kelas tersebut nantinya akan diberikan perlakukan yang berbeda. Kelas eksperimen akan diberikan perlakuan melalui model pembelajaran Consept Sentence berbantuan media Audio Visual dan kelas kontrol akan diberikan perlakuan melalui pembelajaran konvensional. Untuk kelompok eksperimen digunakan kelas Ila di SD Negeri 11 Sesetan dan untuk kelompok kontrol digunakan kelas II di SD Negeri 18 Sesetan. Kelompok penelitian tersebut dipilih karena telah melalui sistem pengundian.

Dalam penelitian ini terdapat faktor yang mempengaruhi hasil penelitian yaitu validitas internal. Instrumen yang mempunyai validitas internal, bila kriteria yang ada dalam instrumen secara rasional telah mencerminkan apa yang diukur. "Validitas internal bersumber dari pelaksanaan penelitian itu sendiri" (Setyosari, 2013 : 180). Adapun validitas internal dalam penelitian ini adalah sebagai berikut. 1) kematangan atau maturasi (maturation), dan 2) pengujian sebelumnya (pretesting). Dalam suatu penelitian tidak hanya faktor internal yang dapat memperngaruhi, terdapat juga faktor lain yang bersifat eksternal yang memiliki pengaruh pada hasil penelitiannya yaitu validitas eksternal. Menurut Setyosari (2013 : 192) "validitas eksternal merujuk pada generalisasi dan berkenaan dengan seberapa jauh kita dapat menggeneralisasi hasil penelitian di luar latar penelitian:. Beberapa ancaraman yang berkaitan dengan validitas eksternal meliputi : inteaksi antara perlakukan dan orang, interaksi antara perlakuan dan latar, dan interaksi antara perlakuan dan waktu. Cara yang dapat dilakukan untuk mengontrol validitas eksternal yaitu dengan menunjukan melalui pengamatan dan wawancara secara kualitatif yang menyatakan bahwa tidak ada orang-orang dan latar tertentu atau khusus dan peristiwa-peristiwa historis yang akan dapat menghambat generalisasi hasil penelitian.

Data yang dikumpulkan dalam penelitian ini adalah data tentang keterampilan menulis permulaan Bahasa Indonesia siswa kelas II SD Gugus Patimura Denpasar Selatan Tahun Ajaran 2017/2018. metode pengumpulan data yang digunakan adalah tes. "Tes merupakan serentetan pertanyaan atau latihan atau alat lain yang digunakan untuk mengukur keterampilan, pengetahuan, intelegensi, kemampuan atau bakat yang dimiliki oleh individu atau kelompok" (Arikunto, $2013: 46$ ). Metode tes digunakan untuk memperoleh data tentang keterampilan menulis. Tes keterampilan menulis permulaan yang akan digunakan yaitu tes uraian. Adapun instrumen yang digunakan untuk menilai tes keterampilan menulis permulaan adalah rubrik penilaian yang mana komponen yang dinilai yaitu susunan pola kalimat, penggunaan huruf kapital dan tanda baca, bentuk tulisan, ukuran tulisan dan kebersihan tulisan. Instrumen yang dibuat pada penelitian ini berupa tes uraian yang telah di uji dengan uji validitas isi yang memeriksa kisi-kisi dengan rubrik yang telah dibuat agar tes tetap terarah pada tujuan pengukuran tes, dan uji validitas konstrak yang dilakukan oleh dosen pembimbing dan guru SD sebagai penilai.

Teknik analisis data yang digunakan untuk uji hipotesis yaitu menggunakan uji-t. Sebelum dilakukan uji hipotesis terlebih dahulu dilakukan uji prasyarat analisis yaitu dengan uji normalitas sebaran data dengan uji Kolmogorov-Smirnov, uji homogenitas varians menggunakan uji F. Hipotesis yang diuji dalam penelitian ini adalah :

$H_{o} \quad$ : Tidak terdapat perbedaan keterampilan menulis antara kelompok siswa yang dibelajarkan melalui model pembelajaran Consept Sentence berbantuan media Audio Visual dengan kelompok siswa yang dibelajarkan melalui pembelajaran konvensional pada siswa kelas II SD Gugus Patimura Denpasar Selatan Tahun Ajaran 2017/2018.

$$
t=\frac{\overline{X_{1}}-\overline{X_{2}}}{\sqrt{\frac{\left(n_{1}-1\right) s_{1}^{2}+\left(n_{2}-1\right) s_{2}^{2}}{n_{1}+n_{2}-2}\left(\frac{1}{n_{1}}+\frac{1}{n_{2}}\right)}}
$$

(Sugiyono, 2015:273)

Keterangan :

$\bar{X}_{1}$ : rata - rata skor pretest kelompok eksperimen

$\bar{X}_{2}$ : rata - rata skor pretest kelompok kontrol

$s_{1}^{2}$ : varians kelompok eksperimen 
JP2, Vol 2 No 2, Tahun 2019

p-ISSN : 2614-3909 e-ISSN : 2614-3895

$s_{2}^{2}$ : varian kelompok kontrol

$n_{1}$ : jumlah siswa kelompok eksperimen

$n_{2}$ : jumlah siswa kelompok kontrol

Kriteria pengujian adalah jika $t_{\text {hitung }}>t_{\text {tabel }}$ maka $H_{0}$ ditolak. Dimana $t_{\text {tabel }}$ didapat dari tabel distribusi t pada taraf signifikasi $5 \%$ dengan derajat kebebasan $\mathrm{dk}=\left(n_{1}+n_{2}-2\right)$.

\section{Hasil dan Pembahasan}

Hasil analisis penghitungan rerata (mean), ukuran penyebaran data (standar deviası) dan varians hasil keterampilan menulis permulaan siswa dapat dilihat pada tabel berikut ini.

Tabel 1. Rekapitulasi Nilai Keterampilan Menulis Permulaan Siswa Kelas II SD

\begin{tabular}{lcc}
\hline \multicolumn{1}{c}{ Hasil Analisis } & Kelompok Eksperimen & Kelompok Kontrol \\
\hline Mean & 84,183 & 75,208 \\
\hline Standar Deviasi & 9,544 & 11,201 \\
\hline Varians & 91,099 & 125,477 \\
\hline Nilai Maximum & 100 & 92,30 \\
\hline Nilai Minimum & 61,53 & 53,84 \\
\hline
\end{tabular}

Sebelum dilakukan uji hipotesis terlebih dahulu dilakukan uji prasyarat analisis yaitu dengan uji normalitas sebaran data dan uji homogenitas varians. Uji normalitas dilakukan untuk mengetahui frekuensi skor sebaran data berdistribusi normal atau tidak. Untuk itu pengujian normalitas sebaran data menggunakan analisis Kolmogorov-smirnov dengan kriteria $K S_{\text {hitung }}$ $>K S_{\text {tabel }}$ maka Ha diterima Ho ditolak artinya data tidak berdistribusi normal dan sebaliknya apabila $K S_{\text {hitung }} \leq K S_{\text {tabel }}$ maka Ho diterima Ha ditolak artinya data berdistribusi normal. Pengujian dilakukan pada taraf signifikansi $5 \%(0,05)$.

Tabel 2. Rekapitulasi Hasil Uji Normalitas Sebaran Data

\begin{tabular}{ccccc}
\hline Kelompok sampel & Jumlah sampel & KShitung & KStabel & Kesimpulan \\
\hline Eksperimen & 36 & 0,204 & 0,221 & Berdistribusi Normal \\
\hline Kontrol & 36 & 0,188 & 0,221 & Berdistribusi Normal \\
\hline
\end{tabular}

Untuk menguji homogenitas varians kelompok adalah untuk meyakinkan bahwa perbedaan yang diperoleh uji-t benar - benar berasal dari perbedaan antara kelompok, buka disebabkan oleh perbedaan di dalam kelompok. Dalam penelitian ini uji homogenitas varians dilakukan dengan uji F. Kriteria pengujian adalah jika $F_{\text {hitung }}<F_{\text {tabel }}$ maka sampel dinyatakan homogen. Pengujian dilakukan pada taraf signifikansi $5 \%$ dengan derajat kebebasan untuk pembilang $n 1-1(36-1=35)$ dan derajat kebebasan untuk penyebut $n 2-1$ $(36-1=35)$.

Tabel 3. Uji Homogenitas Varians

\begin{tabular}{ccccccc}
\hline Sampel & Mean & SD & Varians & $F_{\text {hitung }}$ & & Kesimpulan \\
& & & & & $F_{\text {tabel }}$ & \\
\cline { 1 - 3 } Eksperimen & 84,183 & 9,544 & 91,099 & \multirow{2}{*}{1,377} & \multirow{2}{*}{1,78} & $\begin{array}{c}\text { Data } \\
\text { Homogen }\end{array}$ \\
\hline Kontrol & 75,208 & 11,201 & 125,477 & &
\end{tabular}

Dari hasil penghitungan $F=\frac{\text { varians terbesar }}{\text { varians terkecil }}=\frac{91,099}{125,477}=1,377$ diperoleh $F_{\text {hitung }}=$ 1,377 , sedangkan $F_{\text {tabel }}$ pada taraf signifikansi $5 \%$ dengan derajat kebebasan $(\mathrm{dk})(35,35)=$ 1,78. Hal ini berarti $F_{\text {hitung }}<F_{\text {tabel }}$ data nilai keterampilan menulis permulaan kelompok eksperimen dan kelompok kontrol adalah homogen. 
Data nilai keterampilan menulis Bahasa Indonesia siswa telah memenuhi syarat normal dan homogen, selanjutnya dilakukan pengujian hipotesis. Adapun hipotesis penelitian yang diuji adalah sebagai berikut. $H_{0}: \mu_{1}=\mu_{2}$

Tidak terdapat perbedaan keterampilan menulis antara kelompok siswa yang dibelajarkan melalui model pembelajaran Consept Sentence berbantuan media Audio Visual dengan kelompok siswa yang dibelajarkan melalui pembelajaran konvensional pada siswa kelas II SD Gugus Patimura Denpasar Selatan Tahun Ajaran 2017/2018. Berdasarkan hal tersebut maka uji statistik yang digunakan dalam penelitian ini adalah uji-t. Dengan kriteria pengujian adalah Ho ditolak jika $t_{\text {hitung }}>t_{\text {tabel }}$. Nilai tabel dihitung dari $\mathrm{dk}=\mathrm{n} 1+\mathrm{n} 2-2$. Hasil perhitungan uji hipotesis disajikan dalam tabel berikut ini.

Tabel 4. Uji Hipotesis

\begin{tabular}{ccccccc}
\hline \multicolumn{1}{c}{ Kelas } & Mean & Varians & $\mathrm{N}$ & $t_{\text {hitung }}$ & $t_{\text {tabel }}$ & Kesimpulan \\
\hline Kelas Eksperimen & 84,183 & 91,099 & 36 & \multirow{2}{*}{3,659} & \multirow{2}{*}{2,000} & Ho ditolak \\
\hline Kelas Kontrol & 75,208 & 125,477 & 36 & & & \\
\hline
\end{tabular}

Dengan demikian nilai ${ }^{t_{\text {hitung }}}=3,634>t_{\text {tabel }} 2,000$ sehingga Ho ditolak. Ini berarti terdapat pengaruh model pembelajaran Consept Sentence berbantuan media Audio Visual terhadap keterampilan menulis Bahasa Indonesia. Maka dapat ditarik kesimpulan bahwa terdapat pengaruh model pembelajaran Consept Sentence berbantuan media Audio Visual terhadap keterampilan menulis Bahasa Indonesia siswa kelas II SD Gugus Patimura Denpasar Selatan Tahun Ajaran 2017/2018.

Berdasarkan hasil analisis data dengan menggunakan uji-t diperoleh $t_{\text {hitung }}=3,659$.

Pada taraf signifikansi $5 \%$ dan derajat kebebasan $(\mathrm{dk})=36+36-2=70$ maka diperoleh $t_{\text {tabel }}=$ 2,000. Berdasarkan hasil tersebut diperoleh $t_{\text {hitung }}=3,659>t_{\text {tabel }}=2,000$. Dari perbandingan tersebut maka Ho ditolak. Dalam pembelajaran menulis permulaan, pembelajaran dengan model Consept Sentence berbantuan media Audio Visual secara keseluruhan lebih baik dibandingkan dengan pembelajaran tanpa media pendukung yang ditunjukan dengan nilai rata - rata kelompok siswa eksperimen yaitu kelas Ila SD Negeri 11 Sesetan $\bar{X}=84,183$ dan nilai rata - rata kelompok siswa kontrol yaitu kelas II SD Negeri 18 Sesetan $\bar{X}=75,208$. Dari nilai rata - rata kelas eksperimen dan kelas kontrol maka diperoleh nilai rata - rata kelas eksperimen lebih besar dari pada nilai rata - rata kelas kontrol $(\bar{X}=84,183>\bar{X}=75,208)$.

Dalam proses pembelajaran, terkadang kurang adanya inovasi pembelajaran selain itu penggunaan media untuk menarik minat siswa dalam belajar masih kurang. Dalam setiap pembelajaran siswa diharapkan tidak hanya menggunakan guru sebagai sumber belajar, melainkan peran aktif siswa dalam setiap proses pembelajaran menggunakan pengetahuan dan pendapat yang mereka miliki juga dapat meningkatkan proses pembelajaran. Untuk menumbuhkan minat siswa dalam belajar, guru perlu menerapkan model dan menggunakan media yang dapat menunjang proses pembelajaran tersebut. Banyak model yang dapat digunakan guru sebagai inovasi dalam pembelajaran untuk melatih keterampilan menulis siswa. Salah satunya dengan menggunakan model pembelajaran Consept Sentence dan dibantu dengan media Audio Visual dalam bentuk video yang memungkinkan siswa tertarik untuk belajar dan berperan aktif dalam setiap proses pembelajarannya. Sebaliknya jika pembelajaran tanpa model atau media pembelajaran yang mendukung, minat siswa untuk belajar tidaklah optimal. Kurangnya minat siswa dalam belajar akan mempengaruhi hasil belajar siswa. Proses pembelajaran menulis permulaan yang dibelajarkan melalui model pembelajaran Consept Sentence yang menggunakan kata kunci sebagai bantuan untuk siswa berpikir kreatif mengembangkan buah pikiran yang akan disampaikan dalam bentuk tulisan dan dibantu dengan media Audio Visual yang memungkinkan siswa mengembangkan kata kunci untuk menceritakan isi dari video yang ditampilkan. Maka secara terus menerus kemampuan berpikir tingkat tinggi siswa akan terbentuk. Hal ini karena model pembelajaran Consept Sentence berbantuan media Audio Visual merangsang siswa untuk menuangkan ide ke dalam bahasa tulis dengan pengetahuan yang mereka miliki sehingga mereka paham dengan yang dipelajarinya. 
Dengan mengunakan model pembelajaran Consept Sentence berbantuan media Audio Visual siswa mampu menceritakan isi dari video yang dituangkan ke dalam bahasa tulis dan proses pembelajaran menjadi efektif dan efisien. Kata kunci dan video yang ditampilkan akan menarik minat siswa dalam belajar sehingga hasilnya akan berpengaruh terhadap keterampilan siswa dalam menulis. hal ini disebabkan karena siswa kelas II tertarik dengan gambar animasi yang menarik perhatian sehingga minat siswa untuk belajar akan lebih optimal.

Hasil temuan penelitian ini memiliki persamaan dengan penelitian sebelumnya yang relevan dan memperkuat hasil penelitian yang diperoleh. Hal tersebut didukung oleh penelitian Sumerti (2014) terdapat perbedaan yang signifikan keterampilan menulis pada pelajaran Bahasa Indonesia antara siswa yang dibelajarkan menggunakan model pembelajaran Consept Sentence berbantuan gambar berseri dengan siswa yang dibelajarakan menggunakan pembelajaran konvensional pada kelas V SDN 22 Dauh Puri Denpasar tahun pelajaran $2013 / 2014$. Penelitian ini dibuktikan dengan hasil $\left(t_{\text {hitung }}=2,70>t_{\text {tabel }}=2,000\right.$ ).

Mahardika (2017) terdapat perbedaan yang signifikan kompetensi pengetahuan IPA antara siswa yang dibelajarkan menggunakan model pembelajaran Tandur berbantuan media audio visual dan siswa yang dibelajarkan menggunakan pembelajaran konvensional pada siswa kelas V SD Gugus Srikandi Tahun Ajaran 2016/2017. Penelitian ini dibuktikan dengan hasil $\left(t_{\text {hitung }}=3,650>t_{\text {tabel }}=2,000\right)$ dan nilai rata - rata kompetensi pengetahuan IPA kelompok eksperimen $\bar{X}=78,13 \geq \bar{X}=70,55$ nilai rata - rata kompetensi pengetahuan IPA kelompok kontrol.

Berdasarkan hasil analisis uji $-\mathrm{t}$ diperoleh $t_{\text {hitung }}=3,659>t_{\text {tabel }}=2,000$, ini berarti terdapat perbedaan yang signifikan keterampilan menulis Bahasa Indonesia kelompok siswa yang dibelajarkan melalui model pembelajaran Consept Sentence berbantuan media Audio Visual dengan kelompok siswa yang dibelajarkan dengan pembelajaran konvensional. Maka didapatkan simpulan bahwa terdapat pengaruh model pembelajaran Consept Sentence berbantuan media Audio Visual terhadap keterampilan menulis Bahasa Indonesia siswa kelas II Gugus Patimura Denpasar Selatan pada taraf signifikansi 5\% diterima. Hal ini mengandung arti bahwa yang dibelajarkan melalui model pembelajaran Consept Sentence berbantuan media Audio Visual, hasil belajarnya lebih baik dibandingkan tanpa menggunakan model atau media dalam proses pembelajaran.

Hal ini mendukung hipotesis yang menyatakan bahwa terdapat pengaruh model pembelajaran Consept Sentence berbantuan media Audio Visual terhadap keterampilan menulis Bahasa Indonesia siswa kelas II SD Gugus Patimura Denpasar Selatan Tahun Ajaran 2017/2018. Berdasarkan hasil analisis data maka dapat disimpulkan bahwa model pembelajaran Consept Sentence berbantuan media Audio Visual berpengaruh terhadap keterampilan menulis Bahasa Indonesia siswa kelas II SD Gugus Patimura Denpasar Selatan Tahun Ajaran 2017/2018. Hal ini dibuktikan dengan diperoleh ${ }^{t_{\text {hitung }}}=3,659$.

\section{Simpulan dan Saran}

Pada taraf signifikansi $5 \%$ dan derajat kebebasan $(\mathrm{dk})=36+36-2=70$ maka diperoleh $t_{\text {tabel }} 2,000$. Berdasarkan hal tersebut, diperoleh $t_{\text {hitung }}=3,659>t_{\text {tabel }}=2,000$. Serta rata - rata keterampilan menulis permulaan kelompok eksperimen $\bar{X}=84,183$ dan rata - rata kelompok kontrol $\bar{X}=75,208$.

Berdasarkan hasil penelitian, pembahasan dan simpulan, maka diajukan beberapa saran kepada pihak - pihak sebagai berikut.

1) Guru, disarankan menggunakan model pembelajaran yang dapat mengaktifkan siswa dalam proses pembelajaran. Penggunaan media yang dapat menarik minat dan perhatian siswa dalam belajar agar pembelajaran berlangsung dengan efektif dan menyenangkan. 2) Kepala sekolah, disarankan menggunakan hasil penelitian ini sebagai pendukung untuk mengembangkan kinerja guru dalam proses pembelajaran agar guru memiliki inovasi - inovasi dalam pembelajaran dan menciptakan suasana pembelajaran yang menyenangkan dan menjadikan sekolah yang unggul dan inovatif. 3) Peneliti lain yang berminat untuk mengadakan penelitian lebih lanjut tentang model pembelajaran Consept Sentence berbantuan media Audio Visual pada mata pelajaran Bahasa Indonesia maupun mata pelajaran yang lainnya, agar memperhatikan kendala - kendala yang dialami dalam penelitian ini sebagai bahan 
pertimbangan untuk perbaikan dan penyempurnaan penelitian yang akan dilaksanakan guna memperoleh hasil yang lebih optimal.

\section{Daftar Pustaka}

Arikunto, Suharsimi. 2013. Dasar-dasar Evaluasi Pendidikan. Jakarta : Bumi Aksara.

Awing ,Ikawati (2017). Keefektifan Model Pembelajaran Kooperatif Tipe Concept Sentence Dalam Keterampilan Menulis Karangan Deskripsi Bahasa Jerman Siswa Kelas Xi Ipa Sma Negeri 12 Makassar . Jurnal Pendidikan Bahasa Asing dan Sastra Volume 1 No.1 Maret 2017

Cahya , Desi (2015). Pengaruh Model Pembelajaran Concept Sentence Terhadap Kemampuan Menulis Deskripsi Sederhana Peserta Didik Tunarungu Kelas VII . Jurnal Ortopedagogia, Volume 1, Nomor 4, Juli 2015

Mahardika, I Gusti Ngurah Putu Putra. 2017. Pengaruh Model Pembelajaran Tandur Berbantuan Media Audio Visual Terhadap Kompetensi Pengetahuan Ipa Siswa Kelas V. Mimbar PGSD, Vol 5, No 2. (diakses pada tanggal 29 januari 2018).

Nurlaila, Maryam (2015). Pengaruh Bahasa Daerah (Ciacia) Terhadap Perkembangan Bahasa Indonesia Anak Usia 2 Sampai 6 Tahun Di Desa Holimombo Jaya . Jurnal Retorika, Volume 9, Nomor 2, Agustus 2016

Munirah (2015). SISTEM PENDIDIKAN DI INDONESIA: antara keinginan dan realita . Jurnal Auladuna, Vol. 2 No. 2 Desember 2015

Qurrati , Nida (2018). Pengaruh Model Concept Sentence Terhadap Keterampilan Menulis Karangan Sederhana Pada Siswa Kelas Iv Sdn Kerangkulon 1 Demak . Jurnal Sekolah (JS). Vol 2 (2) Maret 2018,

Setyosari, Punaji. 2013. Metode Penelitian Pendidikan dan Pengembangan. Jakarta : PRENADAMEDIA GROUP.

Shoimin, Aris. 2014. 68 Model Pembelajaran Inovatif dalam Kurikulum 2013. Yogyakarta: ARRUZZ MEDIA.

Sugiyono. 2015. Metode Penelitian Pendidikan. Bandung : CV ALFABETA.

Sumerti, Ni Luh. 2014. Pengaruh Model Pembelajaran Kooperatif Tipe Consept Sentence Berbantuan Media Gambar Berseri Terhadap Keterampilan Menulis Siswa Kelas V Sdn 22 Dauh Puri. Mimbar PGSD, Vol 2, No 1. (diakses pada tangga 29 januari 2018).

Tarigan, Henry Guntur. 2013. Menulis. Bandung : CV Angkasa.

Wati, Ega Rima. 2016. Ragam Media Pembelajaran. Yogyakarta : Kata Pena

Wartini (2017). Penerapan Model Pembelajaran Complete Sentence dalam Meningkatkan Keterampilan Menulis Karangan . Jurnal Mimbar Sekolah Dasar, Vol 4(3) 2017, 256-263 DOI: $10.17509 / \mathrm{mimbar}-$ sd.v4i3.8477 